\title{
Claves paisajísticas de la conformación de algunos parques nacionales muy significativos en Estados Unidos y México, y su relación con la política española de parques nacionales
}

\section{Landscape keys in the shaping of some very significant national parks in the United States and Mexico, and their relationship with the Spanish national parks policies}

\author{
Manuel Mollá Ruiz-Gómez ${ }^{1}$
}

\begin{abstract}
RESUMEN
Estados Unidos fue la nación pionera en la creación de parques nacionales e influyó, con sus decisiones y leyes, en un proceso que, en pocos años, se extendería por el resto del mundo. Unas décadas después, en los años diez del siglo xx, México y España seguirían el ejemplo, influidos de diferentes maneras por la política conservacionista norteamericana. Este artículo pretende ofrecer la historia de los orígenes de los parques nacionales en los tres países, su vinculación con las ideas de paisaje que en aquellos momentos se imponían en Occidente, y las diversas vicisitudes que se dieron hasta que la figura del parque nacional se impuso como elemento fundamental para la conservación de la naturaleza, amenazada por distintas circunstancias en los tres países mencionados y en la mayor parte del planeta.
\end{abstract}

Palabras Clave: parques nacionales; Estados Unidos; Pedro Pidal; conservación de la naturaleza.

* Este trabajo se ha realizado dentro del Proyecto de Investigación,"La valoración patrimonial e identitaria del paisaje en España (1875-2010): claves geográficas, culturales y políticas", CSO2012-38425, financiado por el Ministerio de Economía y Competitividad.

${ }^{1}$ Profesor titular de Análisis Geográfico Regional, Departamento de Geografía de la Universidad Autónoma de Madrid, manuel.molla@uam.es. 


\begin{abstract}
The United States of America was the nation's pioneer in the creation of national parks and influenced with their decisions and laws, a process that in a few years, would spread worldwide. Decades later, in the second decade of the twentieth century, Mexico and Spain follow suit, influenced in different ways by the American conservationist policy. This paper offers the history of the origins of the national parks in the three countries, their attachment to the ideas of landscape at the time imposed in the West, and the various events that took place until the figure of the national park was imposed as essential to the conservation of nature, threatened by different circumstances in the three countries and most of the planet member.
\end{abstract}

KeY WORDS: National Parks; United States; Pedro Pidal; Nature's Conservancy.

\title{
INTRODUCCIÓN
}

El «parque nacional» como figura de protección de la naturaleza nació en Estados Unidos en 1872 con la creación del de Yellowstone, seguido en 1890 por el de Yosemite. En México se crea en 1917 el parque nacional Desierto de los Leones, que tiene su precedente en 1876, cuando se le declara zona de reserva forestal para preservar sus manantiales, suministradores de agua a la ciudad de México. Esta figura del parque nacional llegó a Europa en 1909 con la creación de nueve en Suecia, en el mismo año en el que se promulgaron las primeras leyes de protección de la naturaleza en ese país. Pocos años después, en 1916, se promulga en España la ley de creación de parques nacionales y, en 1918 , se constituyen los dos primeros, Covadonga y Ordesa. Si bien la forma elegida fue la misma en estos y otros países (en 1879, en Australia se creó el Royal National Park), no lo fue la legislación que los propiciaba y protegía. En Estados Unidos, por ejemplo, la primera ley referente a parques nacionales es la National Park Service Organic Act, durante la presidencia de Woodrow Wilson, en 1916. No es una ley de creación de parques, sino del servicio responsable de la conservación de parques nacionales y monumentos históricos, bajo protección federal. En el caso español, como se ha dicho, se desarrolla una ley específica, muy breve (con tres artículos), para la creación de parques nacionales; mientras que en el caso mexicano, en 1917 se promulga un decreto presidencial para crear el parque nacional Desierto de los Leones. Será el Reglamento que desarrolle la Ley Forestal de 1926, en su artículo 39, el que se refiera específicamente a los parques nacionales:

Los terrenos forestales nacionales, que por su ubicación, configuración topográfica y otras circunstancias, constituyan una belleza natural propicia para el re- 
creo popular y fomento del turismo, serán declarados por decreto del Ejecutivo, parques nacionales, previa proposición del Servicio Forestal.

La ley estadounidense venía a decir algo similar al Reglamento de 1918 o la ley española. En el caso de la Organic Act, su artículo $2^{\circ}$ dice:

The service thus established shall promote and regulate the use of the Federal areas known as national parks, monuments, and reservations hereinafter specified by such means and measures as conform to the fundamental purposes of the said parks, monuments, and reservations, which purpose is to conserve the scenery and the natural and historic objects and the wildlife therein and to provide for the enjoyment of the same in such manner and by such means as will leave them unimpaired for the enjoyment of future generations.

Muy semejantes ambos textos al artículo $2^{\circ}$ de la ley española:

Son Parques Nacionales, para los efectos de esta Ley, aquellos sitios o parajes excepcionalmente pintorescos, forestales o agrestes del territorio nacional, que el Estado consagra, declarándolos tales, con el exclusivo objeto de favorecer su acceso por vías de comunicación adecuadas, y de respetar y hacer que se respete la belleza natural de sus paisajes, la riqueza de su fauna y de su flora y las particularidades geológicas e hidrológicas que encierren, evitando de este modo con la mayor eficacia todo acto de destrucción, deterioro o desfiguración por la mano del hombre.

En definitiva, protección de lugares de especial belleza natural y fomento del turismo como bases fundamentales en los tres casos. Sin embargo, los procesos seguidos en los tres países, aunque con algunas semejanzas, tuvieron sus propios caminos.

\section{El ORIGEN DE LOS PARQUES NACIONALES EN ESTADOS UNIDOS}

\section{Los precursores intelectuales}

A lo largo del siglo xix la idea de conservación de la naturaleza fue asentándose sobre la obra de escritores, pintores, filósofos y viajeros o exploradores. Ya en los años veinte de ese siglo, autores como James Fenimore Cooper, por boca de algunos de sus personajes, pone de manifiesto esa nueva actitud hacia la naturaleza. De su obra The Pioneers ${ }^{2}$, de 1823, Hans Huth extrae estas frases, en las que el protagonista, Natty Bumpo, dice: «when I felt lonesome ...I would go into the Catskills and spend a few days on that hill...» «What

${ }^{2}$ The Pioneers es la primera de las cinco novelas que componen su obra Leatherstocking Tales, de la que es The Last of the Mohicans (1826) la más conocida de todas. 
see you when you get there?» Asked Edwards... «Creation, lad, all creation,» said Natty. "How should a man who has lived in towns ... know anything about the wonders of the Woods... None know how often the hand of God is seen in the wilderness, but them that rove it for a man's life». (Huth, 1948: II).

El escritor y filósofo Ralph Waldo Emerson será también uno de los pioneros en escribir en Estados Unidos sobre el concepto de naturaleza y su visión del paisaje. En una de sus obras quizá más divulgadas, el ensayo titulado $\mathrm{Na}$ ture (1836), Emerson conjuga la belleza, buscada por el poeta, con la verdad que persigue el filósofo, para dar forma a un entendimiento de la naturaleza y el paisaje que tiene que ver con la mirada, pero también con una necesaria implicación moral. Escribe el autor:

El encantador paisaje que vi esta mañana está indudablemente compuesto de unas veinte o treinta fincas. Miller posee este campo, Locke aquél, y Manning el arbolado de más allá. Pero ninguno de ellos posee el paisaje. Hay en el horizonte una propiedad que ningún hombre posee, sino aquel cuyos ojos pueden integrar todas las partes, esto es, el poeta. Esta es la mejor parte de las fincas de estos hombres; y, no obstante, a esto no les dan derecho sus títulos territoriales.

Para hablar con verdad, pocas personas pueden ver la Naturaleza. [...] El amante de la Naturaleza es aquel cuyos sentidos interiores y exteriores están ajustados uno a otro; el que ha conservado el espíritu de la infancia en la época de la edad madura. (Emerson, 1904: 5).

No es posible, por no hacer más larga la referencia a escritores, olvidar a Henry David Thoreau, cuyas obras son, sin duda, de las que más han influido en los conservacionistas norteamericanos. De su ensayo Walking (1862), un párrafo que resume el sentimiento del autor frente a «las mejoras del hombre»:

En la actualidad, casi todas las llamadas mejoras del hombre, como la construcción de casas y la tala de bosques y de todos los árboles de gran tamaño, no hacen sino deformar el paisaje y volverlo cada vez más doméstico y vulgar. ¡Un pueblo que comenzase por quemar las cercas y dejar en pie el bosque...! He visto los cercados medio consumidos, perdidos sus restos en medio de la pradera, y un miserable profano ocupándose de sus lindes, con su topógrafo, mientras la gloria se manifestaba en su derredor y él no veía los ángeles yendo y viniendo, sino que se dedicaba a buscar el viejo hoyo de un poste en medio del paraíso. Volví a mirar, y lo vi de pie en medio de un tenebroso pantano, rodeado de diablos; y no hay duda de que había encontrado la linde, tres piedrecillas allí donde había estado hincada una estaca; y mirando más de cerca, vi que el Príncipe de las Tinieblas era el agrimensor. (Thoreau, 2010: 16).

En su obra The Maine Woods (1864), Thoreau recoge sus vivencias de tres excursiones que realizó a los bosques de Maine, en los años 1846, 1853 y 
1857. La segunda parte, titulada "Chesuncook" termina con unas palabras que ponen de manifiesto la lucha del autor por conseguir espacios protegidos (en lo que llama reservas naturales) en los Estados Unidos:

The kings of England formerly had their forests "to hold the king's game," for sport or food, sometimes destroying villages to create or extend them; and I think that they were impelled by a true instinct. Why should not we, who have renounced the king's authority, have our national preserves, where no villages need be destroyed, in which the bear and panther, and some even of the hunter race, may still exist, and not be "civilized off the face of the earth," -our forests, not to hold the king's game merely, but to hold and preserve the king himself also, the lord of creation,- not for idle sport or food, but for inspiration and our own true re-creation? Or shall we, like villains, grub them all up, poaching on our own national domains? (Thoreau, 2004: 155).

Sin embargo, el papel jugado por los pintores y viajeros que recorrieron el Oeste, sobre todo California, fue el decisivo a la hora de conseguir la protección de los primeros grandes paisajes norteamericanos. Pintores paisajistas que dieron a conocer los nuevos territorios y que habían formado la que fue escuela pionera del paisajismo de ese país, la Hudson River School. Entre ellos, cabe destacar a Thomas Cole, Frederic Edwin Church, Albert Bierstadt, John Frederick Kensett y Thomas Moran. Primero con los paisajes del Este y posteriormente, algunos de ellos, con los de las Montañas Rocosas y las de California, los norteamericanos de la costa oriental del país comenzaron a tener una visión clara de lo que la naturaleza de los nuevos territorios representaba. De hecho, otro pintor, George Catlin, es reconocido como el precursor del concepto de parque nacional. Catlin, también escritor y viajero, se hizo famoso por sus retratos de nativos americanos y ha pasado a la historia como el más notable en esta actividad. En 1832 viajó aguas arriba del río Missouri, penetrando en territorio indio, y siendo posiblemente el primer norteamericano que lo hizo. Desde esas tierras escribió una carta al New York Daily Commercial Advertiser, en 1833, en la que concibe la idea de crear espacios protegidos en esos territorios. Dice así:

[These realms] might in the future be seen (by some great protecting policy of government) preserved in their pristine beauty and wilderness, in a magnificent park, where the World Could see for ages to come, the native Indian in his classic attire, galloping his wild horse ....amid the fleeting herds of elks and buffaloes. What a beautiful and thrilling specimen for America to preserve and hold up to the view of her refined citizens and the World, in future ages! A nation's Park, containing man and beast, in all the wild and freshness of their nature's beauty. (Huth, 1948: II). 


\section{El parque estatal de Yosemite}

Estas y otras ideas acabaron fraguando en 1872 con la creación del primer parque nacional en el mundo, el de Yellowstone. Sin embargo, hay un precedente fundamental que bien podría considerarse el primer parque nacional, el de Yosemite (formalmente parque nacional en 1890), que no tuvo inicialmente esta categoría, sino la de parque estatal por unas circunstancias que tienen más que ver con la situación legal de los nuevos territorios integrados en los Estados Unidos, y no tanto con la voluntad de los legisladores, que quedó clara con la protección del Valle de Yosemite en 1864.

La historia de Yosemite se remonta a los años en los que California era todavía parte del Virreinato de Nueva España, pero es el siglo xIx el que marca su destino cuando, poco a poco, se va convirtiendo en objetivo de cazadores y tramperos. Pero Yosemite no era conocido en el Este de los Estados Unidos y ni siquiera la fiebre del oro de California, que se extiende, más o menos, de 1849 a 1855 hizo nada por mejorar este conocimiento. Fue un hecho diferente lo que propició la campaña en defensa de ese territorio y, en particular, de sus árboles, las secuoyas. En 1852 se descubrió la Calaveras Grove of Big Trees, y un año después, un grupo de hombres de negocios cortaron uno de los más espectaculares, la secuoya conocida como Mother of the Trees, de casi cien metros de altura y dieciséis de circunferencia en sus primeros treinta y cinco metros. El objetivo, exhibir una sección del árbol en ciudades del Este y llevarla también a Londres. La exhibición no tuvo éxito porque poca gente creyó que algo de tal tamaño pudiera ser parte de un árbol, o mucho menos que pudiera haber un bosque en California de esas características. Esto, sin embargo, hizo que se levantaran las primeras voces de alarma. Un californiano publicó en Gleason's Pictorial, una revista ilustrada de Boston, una carta de protesta por este hecho: «cruel idea, a perfect desecration to cut down such a splendid tree ... in Europe such a natural production would have been cherished and protected by law; but in this money-making-go-ahead community, thirty or forty thousand dollars are paid for it and the purchaser chops it down and ships it off for a shilling show. We hope that no one will conceive the idea of purchasing Niagara Falls for the same purpose.» (Gleason's Pictorial, 1853: 216. En Huth, 1948: IV). Tras la protesta, la alabanza de esos árboles, merecedores de peregrinación para ser contemplados, en palabras del autor. En 1857, James Russell Lowell ${ }^{3}$ publicó un

${ }^{3}$ Ese mismo año se fundó en Boston la revista de carácter cultural y literario The Atlantic Monthly, de la que fue su primer editor el propio Lowell y entre cuyos fundadores estaban Ralph Waldo Emerson, Oliver Wendell Holmes, Sr. y Henry W. Longfellow. 
artículo titulado "Humanity to Trees", en el que se pedía la creación de una sociedad para prevenir la crueldad en los árboles. Un año más tarde, en Harper's Weekly se recordaba que los grandes árboles seguían siendo «mondados» «with as much neatness and industry as a troupe of jackals would display in clearing the bones of a dead lion.» (Huth, 1948: IV). Ese mismo año, 1958, Oliver W. Holmes publicó en su colección de ensayos Autocrat of the Breakfast Table 4 , uno titulado Talk on Trees, profesando su pasión por estos grandiosos árboles. Lo que en principio fue un incidente, la tala del gran árbol, tuvo, sin embargo, mucha más repercusión en la Costa Este que el propio descubrimiento de Yosemite. En 1855, el pintor Thomas A. Ayers hizo sus primeros dibujos del Valle, algunos de los cuales fueron litografiados, lo que, unido a otros textos hizo de Yosemite un lugar conocido en todo el país.

\section{FIGURA 1}

EL PRIMER DIBUJO HECHO EN YOSEMITE, POR THOMAS A. AYERS (1855)

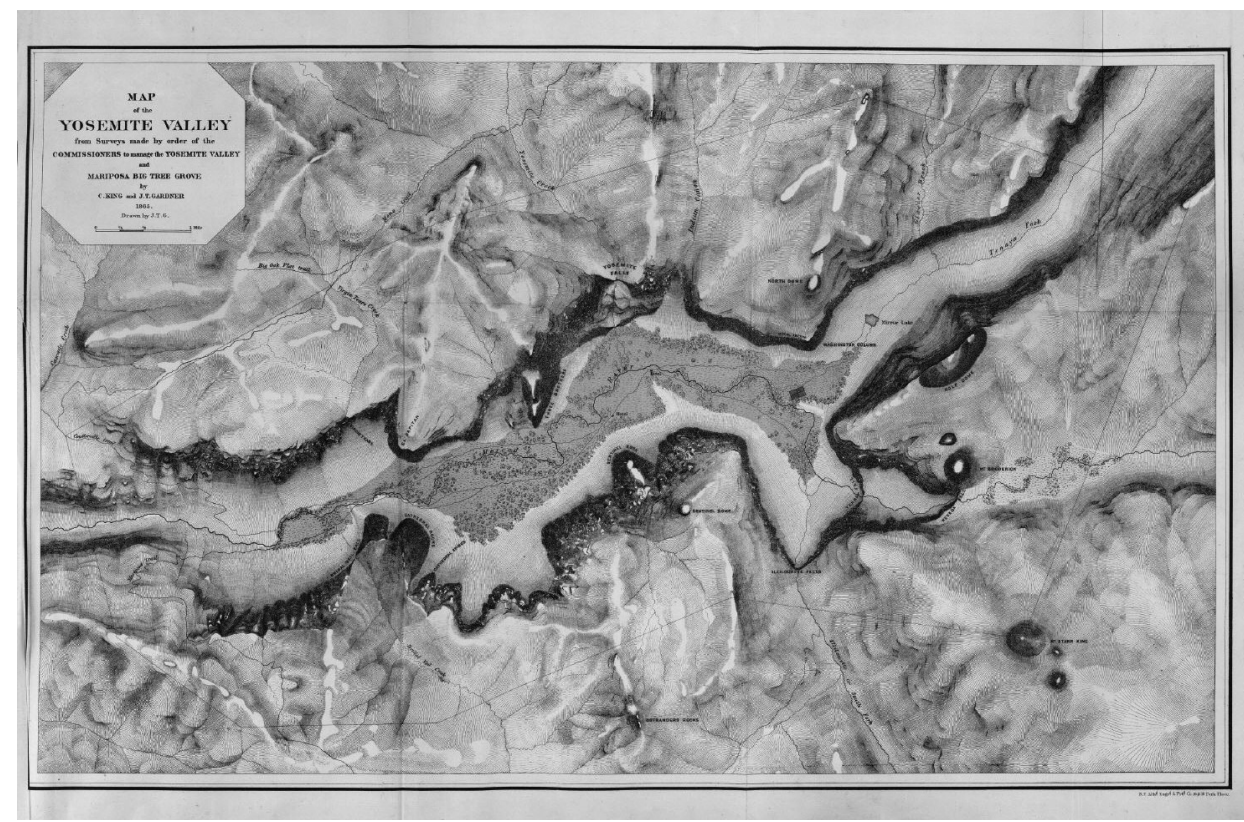

Fuente: Russell, 1947: XVIII.

${ }^{4}$ La colección se publicó en los años 1857 y 1858 en The Atlantic Monthly. 
Quizá la más notable de las publicaciones de la época fue el manual para viajeros del pintor Thomas A. Richards, de 1857, titulado Ilustrated Handbook of American Travel (luego conocido por el nombre de la editorial como Appleton's Handbook). En él se incluía ya un texto breve sobre Yosemite y una imagen del Mirror Lake.

La fotografía no quedó al margen de toda esta difusión, destacando las de dos fotógrafos, primeros en recorrer con sus cámaras la región, Charles L. Weed y Robert H. Vance.

En cualquier caso, fue la labor del político californiano Thomas Starr King quien dio el mayor impulso a la necesidad de proteger el Valle de Yosemite. Primero con sus artículos publicados en la Boston Evening Transcription, entre finales de 1860 y comienzos de 1861, además de la ayuda recibida por algunos personajes que tuvieron un papel decisivo también en el desarrollo del proyecto, sobre todo Israel Ward Raymond y Frederick Law Olmsted. Raymond, representante en California de la Central American Steamship Transit Company de Nueva York, escribió al senador John Conness una carta que sería definitiva en todo el proyecto de protección del Valle. Junto con unas vistas del lugar, Raymond describe las bellezas de Yosemite y solicita que se protejan, de forma inalienable y para siempre, para uso y recreo de la población. En respuesta a la carta, el senador Conness solicitó a J. W. Edmonds, Comisionado de la Oficina General de Tierras (General Land Office) que elaborara un proyecto de ley con el fin de enviarlo cuanto antes al Senado de los Estados Unidos. El proyecto se aprobó y el 29 de junio de 1864 fue firmado por el Presidente Lincoln. El hecho notable es que, si bien el parque quedaba bajo la jurisdicción del estado de California, recibiría subvenciones del Gobierno Federal para que se cumpliesen las normas específicas de uso público, para disfrute y recreo de los visitantes.

El 28 de septiembre de ese mismo año, el gobernador de California anunció la subvención concedida y dio a conocer los miembros de la comisión, presidida por Frederick Law Olmsted, quien la presidiría. Inmediatamente Olmsted se puso a trabajar en las medidas necesarias para la protección del nuevo parque, por lo que pidió que se estudiara el territorio con un equipo dirigido por el responsable del California Geological Survey, Josiah D. Whitney y en el que participaron los geólogos Clarence King y James T. Gardner, que levantarían el primer mapa de la región, y el fotógrafo Carleton Watkins, que fotografió el mapa para incluirlo en la primera guía que se hizo del parque (Whitney, 1870). 


\section{FIGURA 2}

\section{MAPA DEL VALLE DE YOSEMITE, ELABORADO POR CLARENCE KING Y JAMES T. GARDENER (1868)}

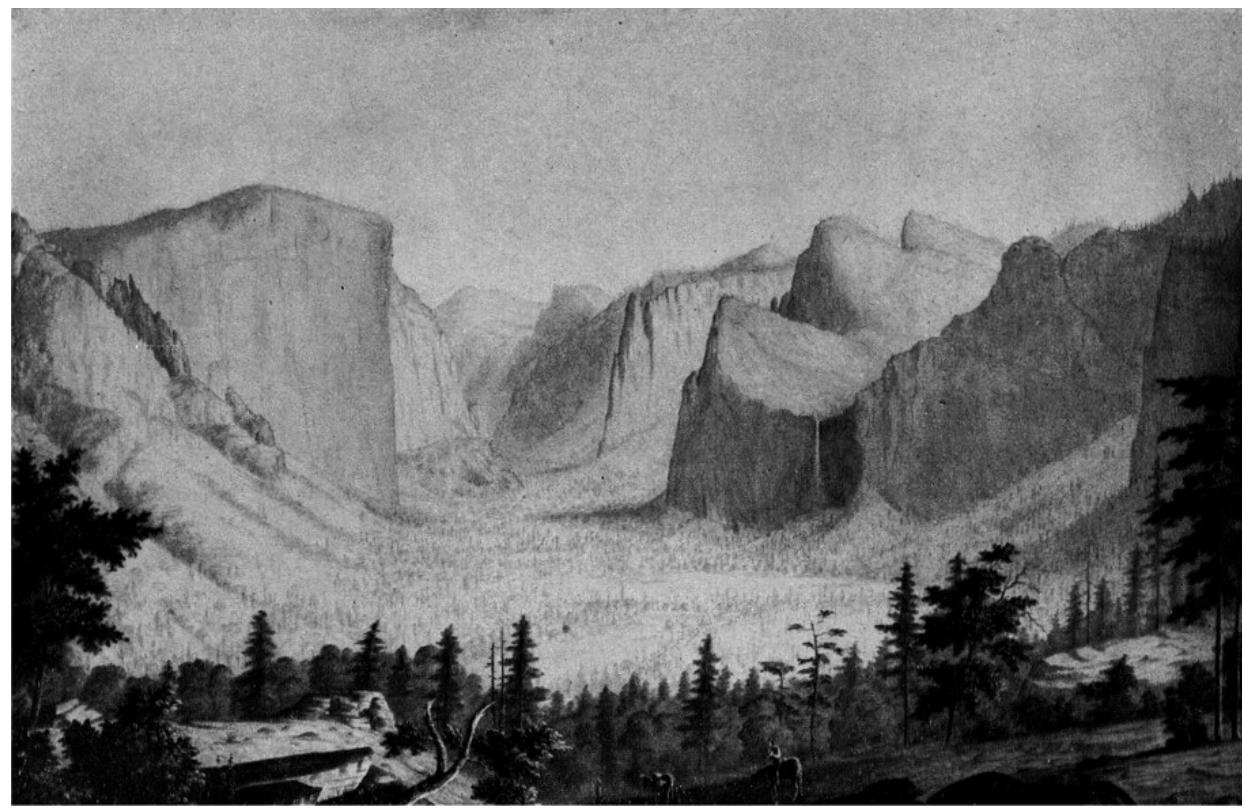

Fuente: Archivo en red de la David Rumsey Historical Map Collection.

El periodista Samuel Bowles escribió sobre la decisión del Congreso de los Estados Unidos lo siguiente, en 1869, todavía tres años antes de que se declarara Yellowstone parque nacional:

The journey hither from San Francisco is both a tedious and an expensive one, and so a barrier to the extensive popular enjoyment of the rare works of nature here gathered. But the number of visitors is rapidly increasing; last year there were in all but one hundred, and already this season over three hundred persons have come into the Valley. Congress has ceded this territory of the Valley to the State of California for reservation and preservation as a spot for public resort and popular enjoyment; and a laudable and promising effort is now making, under the lead of Mr. Frederick Law Olmsted, the manager of Mariposa estate, to secure and appropriation from the State treasury for improving the means of access, laying out paths among its beauties, and providing cheap yet agreeable accommodations for visitors. This wise cession and dedication by Congress, and proponed improve- 
ment by California, also includes the nearest of the Groves of Big Trees, which is to be similarly held and protected for the public benefit, and furnishes an admirable example of other objects of natural curiosity and popular interest all over the Union. New York should preserve for popular use both Niagara Falls and its neighborhood and a generous section of her famous Adirondacks, and Maine one of her lakes and its surrounding woods. (Bowles, 1869: 230-231).

No ahorra Bowles elogios y comparaciones sobre la naturaleza de Yosemite. Escribe en un momento dado:

The one distinguishing feature is a double wall of perpendicular granite, rising from a half a mile to a mile in high, and inclosing a valley not more than half a mile in width on the average, and from ten to fifteen miles in length. If is a fissure, a chasm, rather than a valley, in solid rock mountains; there is not breadth enough in it for even one of its walls to lie down; and yet it offers all the fertility, all the beauties of a rich valley. There is meadow with thick grass; there are groves of pine and oak, the former exquisite in form and majestic in size, rising often the two hundred and two hundred and fifty feet; there are thickets of willow and birch, bay trees and dogwood, and various flowering shrubs; primrose and cowslip and golden rod and violet and painted cup, more delicate than eastern skies can welcome, make gay garden of all the vacant fields now in August; the aroma of mint, of pine and fir of flower loads the air; the fern family find a familiar home everywhere; and winding in and out among all flows the Merced River, so pure and transparent that you can hardly tell where the air leaves off and the water begins, rolling rapid over polished stones or soft sands, or staying in wide, deep pools that invite the bather and the boat, and holding trout only less rich and dainty than the brook trout of New England. (Bowles, 1869: 224-225).

También escribió, no podía ser de otra manera, sobre las cascadas del Valle:

The Valley above this point separates into two or three narrow canyons, and these are soon walled by the uprising rocks. At the end of one of these, the main branch of the river falls from its upper fountains over two walls, one three hundred and fifty feet high and the other seven hundred, at points half mile apart. The lower shorter fall is called the Vernal, and pours down its whole high without a break, and forms at the base a most exquisite circular rainbow, one of the rarest phenomena in all nature. The upper fall bears the name of Nevada, breaks as it comes over its crest into a grand blossom of spray, and strikes, about half way down its seven hundred feet, the obtruding wall, which thence offers just sufficient slope to keep the water and carry it in chasing, circling lines of foam to the bottom. This is the fall of falls, - there is no rival to it here in exquisite, various, fascinating beauty; and Switzerland, which abounds in Water-falls of like type, holds none of such peculiar charms. (Bowles, 1869: 229). 


\section{FIGURA 3}

\section{UPPER YOSEMITE FALL. PARQUE NACIONAL DE YOSEMITE, CALIFORNIA}

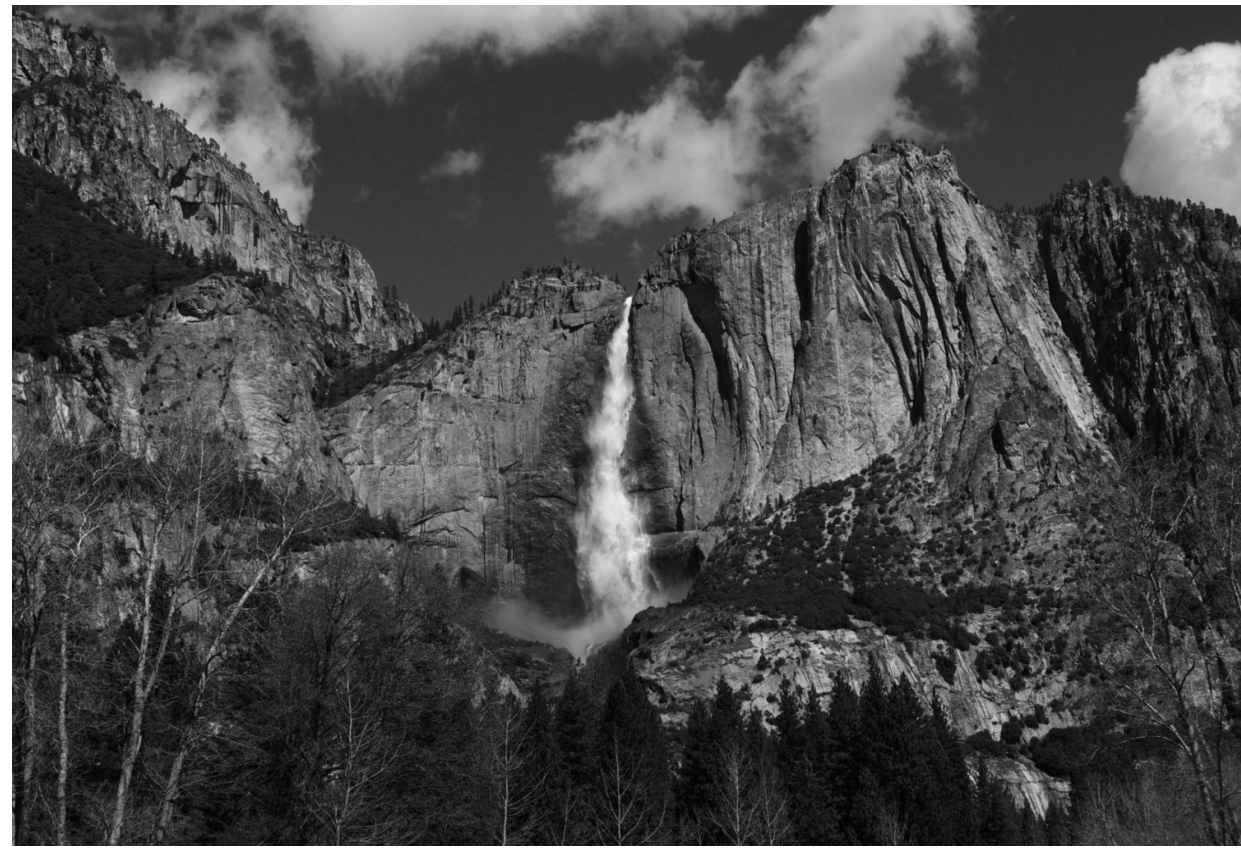

Fotografía: Manuel Mollá (2013).

Frederick Law Olmsted, por su parte, siguió con los esfuerzos para organizar el parque y elaboró un informe aprobado por el comité de Yosemite para presentar en la legislatura de California. Nada se sabe del mismo, pero sí de la carta que el propio Olmsted envió a tres artistas, previa al informe, con algunas preguntas. La carta está dirigida a Virgil Williams, Thomas Hill y el fotógrafo Carleton E. Watkins ${ }^{5}$ y se expresa en los siguientes términos:

I address you in behalf of the Commissioners appointed under the Act of Congress, establishing Yo Semite and Mariposa Grove as a ground for recreation. The action of. Congress with regard to the Yo Semite was doubtless taken in view of the peculiar value of its natural scenery, the purpose of its action was to give the pub-

${ }^{5}$ Thomas Hill había realizado una exitosa exposición de su obra sobre Yosemite en Boston (1868), donde fue aclamado como el pintor de California. Carleton E. Watkins fue uno de los fotógrafos más importantes de la naturaleza de Yosemite. 
lic for all future time the greatest practicable advantage of that scenery, and the duty of the Commission is to secure the accomplishment of that purpose. What effects natural scenery favorably or unfavorably to the enjoyment of mankind is the principal study of your lives and as you are at present making a special study of the scenery of the Yo Semite you may find it convenient to give some thought incidentally to two general questions your advise upon which would be of great service to the Commission:

1st. Are there any conditions affecting the scenery of the Yo Semite unfavorably which it would be in the power of the State to remove, or the further and increased effect of which might be prevented?

2nd. What can be done by the State to enhance the enjoyment now afforded by the scenery of the Yo Semite?

The Commission being required by act of Congress to perform its own duties gratuitiously and no provision having been made for meeting any expenses in the premises, I cannot promise the pecuniary remuneration for your advice which it would be your right to demand, but it is hoped that the importance of the Commission's duty as a field of study for artists and the great interests of the public in having the action by the State well advised present sufficient grounds of apology for requesting your professional assistance as a favor. (Huth, 1948: IV).

Parece ser que los tres habían sido comisionados para realizar un estudio especial sobre las características de los paisajes del parque, con la finalidad de mejorar lo que fuera necesario.

No se puede concluir este apartado sin hacer referencia a John Muir, quien llegó a esa tierra en 1868 e inició una nueva era en la difusión de las bellezas de Yosemite y en la necesidad de insistir en su completa protección. Incluso invitó y consiguió que Ralph W. Emerson, ya muy mayor, hiciera un viaje a ese lugar y admirara su naturaleza. En mayo de 1871 llegó al Valle y esto es lo primero que anotó en su diario de viaje:

15,000 feet, in Tulare County. In Yosemite, grandeur of these mountains perhaps unmatched in the globe; for here they strip themselves like athletes for exhibition, and stand perpendicular granite walls, showing their entire height, and wearing a liberty cap of snow on their head.

Sequoia Gigantea, Pinus Lambertiana, Sugar pine, 10 feet diameter; 300 feet height; cones 18 inches. Pinus Ponderosa, yellow pine. Pinus Albicaulis.

At the request of Galen Clark, our host at Mariposa, and who is, by State appointment, the protector of the trees, and who went with us to the Mammoth Groves, I selected a Sequoia Gigantea, near Galen's Hospice, in the presence of our party, and named it Samoset, in memory of the first Indian ally of the Plymouth Colony, and I gave Mr. Clark directions to procure a tin plate, and have the inscription painted thereon in the usual form of the named trees: and paid him its cost (Emerson, 1914: 354). 
En su invitación a Emerson, escribió Muir:

I invite you to join me in a month's worship with Nature in the high temples of the great Sierra Crown beyond our holy Yosemite. It will cost you nothing save the time and very little of that, for you will be mostly in Eternity. (Huth, 1948: IV).

Muir no se quedó nada más en la defensa de Yosemite y, además de fundar el Sierra Club, con varios cientos de miles de socios en la actualidad y siempre vigilante ante los atentados contra la naturaleza, escribió diez libros y contribuyó a la creación de varios parques nacionales más.

\section{LA PROTECCIÓN DE LA NATURALEZA Y LOS PRIMEROS PARQUES NACIONALES MEXICANOS}

\section{Precedentes durante el siglo XIX}

Las primeras medidas que los gobiernos de la nueva república mexicana tomaron en relación con la naturaleza, lo fueron de carácter forestal y siguiendo, en buena medida, parte de la legislación heredada de época colonial, como la Ordenanza General de Montes y Plantíos de 1784, que recopilaba toda la normativa relativa a los bosques, o las Ordenanzas para el Gobierno de Montes y Arbolados, de 1804, que, señalan algunos autores, fue un auténtico modelo de regulación forestal.

Ya en el México independiente aparecen pronto textos legales y reglamentos destinados a regular la actividad forestal. En 1813 se concede a los ayuntamientos la vigilancia y cuidado de los montes y plantíos del común. Algunos años más tarde, en 1839, el gobierno de la República ordena a los gobernadores que dicten las normas necesarias para evitar las talas de árboles y reponer los destruidos, así como crear nuevos. A lo largo del siglo habrá nuevas disposiciones de carácter forestal, pero será el 1876 cuando se dé el primer paso para la creación de lo que será, poco más de cuarenta años después, el primer parque nacional en México.

En el año 1605, los carmelitas descalzos se instalaron en un convento situado al oeste de la Ciudad de México, en el lugar que se conocerá como Santo Desierto de Nuestra Señora del Carmen de los Montes de Santa Fe (hoy, ex Convento del Desierto de los Leones), con una superficie total superior a las 1.500 hectáreas, en una zona boscosa, predominantemente de coníferas, y en las que dominan las comunidades de Abies religiosa puras o mezcladas, y de Pinus hartwegii. La presencia de algo más de dos siglos de los carmelitas (lo abandonaron por el comienzo de la guerra de independencia) en el convento permitió que esos bosques se conservaran en buen estado. Desde finales del 
siglo XVIII su protección empezó a preocupar al gobierno mexicano, para el aprovechamiento de las aguas de esos parajes, pero no fue hasta el último cuarto del siglo XIX cuando se tomó la decisión. Así, en 1876, se declararon esos montes como zona de reserva forestal e interés público. Lo mismo se hizo en otras regiones del país.

\section{Los primeros parques nacionales y la legislación forestal mexicana}

El 27 de noviembre de 1917, en un decreto publicado en el Diario Oficial de la Federación, firmado por Venustiano Carranza, se crea el Parque Nacional Desierto de los Leones, primero de la historia mexicana. Una vez más, el decreto se reduce a tres artículos, como ocurrió un año antes con la Ley de Parques Nacionales española y la National Park Service Organic Act de los Estados Unidos.

El objetivo de la creación se expone en el propio decreto y dice así:

Que es un deber del Ejecutivo Federal cuidar y fomentar los bienes nacionales especialmente los que en cuya conservación es indiscutible el interés público y siendo propiedad de la Nación el bosque ubicado en la municipalidad de Cuajimalpa, Distrito Federal, conocido con el nombre de "Desierto de Los Leones", tanto por la belleza natural de unos paisajes, como por el alto interés histórico de las ruinas que en él se encuentran, debe ser objeto de una atención especial de parte del Ejecutivo, con tanta mayor razón que dada su proximidad a la capital de la República, puede hacerse de él un centro de recreo al transformarlo en un parque nacional; con fundamento en lo que disponen los artículos 60 de la Ley de 18 de diciembre de 1909 y 44 de la de 21 del mismo mes y año, he tenido a bien expedir el siguiente Decreto.

Una vez más, el paisaje y sus cualidades hacen necesaria su protección, a lo que se suman aquí las ruinas del ex convento. No será, sin embargo, una protección que cubra, bajo una misma administración, como se verá, los aspectos naturales y los históricos, como en el caso estadounidense. El texto del artículo es breve y en él no se incluyen los límites del parque:

Artículo Primero: el terreno nacional ubicado en la municipalidad de Cuajimalpa, conocido con el nombre de "Desierto de los Leones", cuya superficie es de 1.529 hectáreas, se declara parque nacional con el nombre de "Parque Nacional Desierto de los Leones", conservando los linderos que actualmente se le reconocen. Artículo Segundo: la administración, conservación y embellecimiento del parque quedarán a cargo de la Secretaría de Fomento, con excepción de los vestigios históricos que se encuentran cuya conservación y su cuidado dependerá de la Secretaría de Comunicación y Obras Públicas. 
Artículo Tercero: la Secretaría de Fomento queda autorizada para realizar los productos explotables, tales como maderas muertas, árboles enfermos, defectuosos o caducos, y los que alteren y perjudiquen al desarrollo de la vegetación principal; empleando el producto en el mejoramiento del mismo parque; pero, por ningún motivo, otorgará permisos o concesiones, o celebrará contratos con particulares, para que ellos directamente hagan el corte y explotación de los árboles y demás productos forestales. Igualmente, queda prohibida la caza y apacentamiento del ganado dentro del parque ${ }^{6}$.

Dos secretarías de Gobierno, las de Fomento, para la conservación de la naturaleza del parque, y la de Comunicación y Obras Públicas, para sus vestigios históricos, serán las responsables de su conservación. Por otro lado, dadas las características del nuevo parque, las referencias a la protección de su naturaleza, o a todo lo que queda prohibido hacer en el lugar, tiene un carácter exclusivamente forestal.

En definitiva, como en el caso de los Estados Unidos, no será necesaria una ley específica para crear parques nacionales, como sucede en la legislación española. De hecho, la Ley Forestal de 1926, presidencia de Plutarco Elías Calles, no hace ninguna referencia al único parque nacional existente, por lo que habrá que esperar al Reglamento de la Ley, de 13 de octubre de 1927, a que, en su capítulo IV, se desarrolle el articulado referente a los parques nacionales. Cinco artículos de ese capítulo resuelven el asunto de los parques nacionales, que se inicia con el texto siguiente, que corresponde al artículo 39 de dicho Reglamento:

Los terrenos forestales nacionales, que por su ubicación, configuración topográfica y otras circunstancias, constituyan una belleza natural para el recreo popular y fomento del turismo, serán declarados por decreto del Ejecutivo, parques nacionales, previa proposición del Servicio Forestal.

En el caso mexicano no habrá un personal específico de parques, sino que se comisionará a empleados del Servicio Forestal (artículo 47). Por último, se establecen los criterios para que distintos tipos de organizaciones reciban permisos de distinto tipo (artículo 50):

En todos los parques nacionales las organizaciones educativas, municipales, deportivas, agrupaciones de exploradores, de cazadores, etc., tendrán derecho a

${ }^{6}$ Por decreto presidencial de 19 de diciembre de 1983, se expropia e indemniza a la comunidad de San Mateo Tlaltenango y se convierte en parque cultural y recreativo, bajo la administración del Gobierno del Distrito Federal. 
obtener gratuitamente lugares en los que construyan casetas o refugios, clubes campestres y campamentos, pudiendo también ejecutar las obras necesarias, previa autorización que se contendrá en el permiso respectivo, sujetándose en todo al presente Reglamento y demás disposiciones relativas.

Como se recordará, el Decreto de creación del Parque Nacional Desierto de los Leones prohibía expresamente la caza. Nada se decía de otro tipo de construcciones, pero quedan abiertos los permisos de construcción que tantos problemas darán en los futuros parques.

En 1942, durante la presidencia de Manuel Ávila Camacho, se desarrolla el Reglamento de parques nacionales e internacionales, publicado en el Diario Oficial de la Federación el 20 de mayo de ese año. Esa es una particularidad interesante, el hecho de que no sea simplemente un reglamento para los parques mexicanos, sino que se desarrolla pensando en la cooperación con los países vecinos con el fin de poder establecerse también parques internacionales. Hay que señalar, por otro lado, que hasta el presente no se ha creado ningún parque internacional en el que participe México.

En el considerando primero, afirma el Presidente de la República: «Que el Ejecutivo de mi cargo ha venido declarando parques nacionales aquellos sitios de importancia histórica y de gran belleza natural, que constituyen lugares apropiados para el solaz del turismo que los visita». Y respecto a los parques internacionales, afirma en el segundo «que con objeto de fomentar las buenas relaciones que necesariamente deben existir entre México y los países vecinos, este Ejecutivo proyecta establecer diversos parques internacionales, como el medio más apropiado para asegurar dichas buenas relaciones, y para que se conozcan mejor las costumbres y culturas entre dichos países».

Resulta curiosa la consideración sobre los parques internacionales, porque pareciera que tienen más que ver con otro tipo de instalaciones o actividades que con las relativas a la protección de la naturaleza, o eso se desprende de esa necesidad de un mejor conocimiento de costumbres y culturas, ya que, en términos de naturaleza o de paisaje, pocas diferencias se dan a ambos lados de dichas fronteras, salvo las derivadas de actividades en ocasiones muy destructivas, como las talas masivas para el uso agrario de los montes o la instalación, en ocasiones, de fábricas y maquilas. Por otro lado, el fomento del turismo, del primer considerando, es un propósito habitual en todo tipo de declaración, ya sea en Estados Unidos, México o España.

Por lo que se refiere al Reglamento, dice su artículo primero:

Se declaran parques nacionales, mediante decreto del Ejecutivo, según lo establece el artículo 39 del Reglamento de la Ley Forestal de 5 de abril de 1926, aquellos lugares destinados a asegurar la protección de las bellezas escénicas naturales 
y de la flora y fauna de importancia nacional, de las que el público pueda disfrutar mejor al ser puestas bajo la vigilancia oficial.

La administración de los parques, tanto nacionales como internacionales, corresponderá a la Dirección Forestal y de Caza, de la Secretaría de Agricultura y Fomento (artículo $4^{\circ}$ del Reglamento). Añade el Reglamento que cada parque nacional estará al cuidado de un encargado (artículo $7^{\circ}$ ), o un ingeniero forestal en el caso de los parques internacionales (artículo $8^{\circ}$ ). Además, según el artículo $9^{\circ}$ :

El encargado de cada parque nacional e internacional, será el jefe de las corporaciones contra incendios de la zona que se determine, quedando facultado y con apoyo en el artículo 39 de la Ley Forestal vigente, para solicitar la ayuda de autoridades y vecinos de dicha zona para extinguir los siniestros que dentro de su jurisdicción se presenten.

El Reglamento de 1942 tiene mucha mayor importancia si se piensa que durante la presidencia de Lázaro Cárdenas, entre diciembre de 1934 y noviembre de 1940 , se crearon treinta y cuatro parques nacionales, la mitad de los creados hasta 2014, seis de ellos en el estado de Michoacán, en una de cuyas localidades, Jiquilpan de Juárez, había nacido el presidente. Es también destacable la variedad de tamaños, pues oscilan entre las 9,65 hectáreas del Parque Nacional Laguna de Camécuaro, también en Michoacán, y las más de 55.000 del Parque Nacional Cañón del Río Blanco, en el estado de Veracruz.

\section{FIGURA 4}

\section{PARQUE NACIONAL LAGUNA DE CAMÉCUARO, MICHOACÁN}

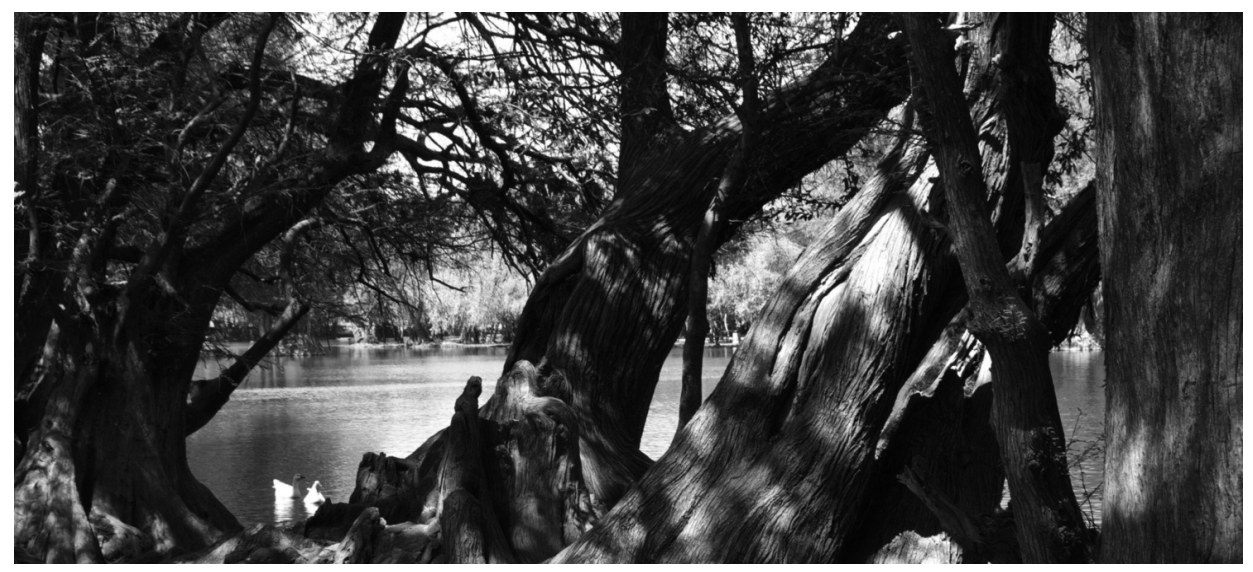

Fotografía: Manuel Mollá (2014). 
Se puede decir, para acabar, que el desarrollo inicial de los parques mexicanos, en cuanto a su nacimiento, queda en una situación intermedia respecto a la de Estados Unidos, donde no hay una ley propiamente dicha y lo que se regula es el servicio de parques, y la española, que necesitó de una ley aprobada en Cortes, ya que todo lo que hubo fueron reglamentos y los parques nacionales se declaraban por decreto presidencial.

\section{LA POLÍTICA ESPAÑOLA Y LOS PRIMEROS PARQUES NACIONALES}

Se ha escrito bastante, y bien, sobre el papel que jugó la Institución Libre de Enseñanza en el desarrollo del excursionismo y del amor a la naturaleza en España, por lo que siempre aparecerán las ideas de Francisco Giner de los Ríos y de sus muchos discípulos en lo que sería la lucha por la protección de los paisajes españoles durante los primeros decenios del siglo xx. Por ello se hace innecesario volver aquí sobre el asunto y conviene centrarse en el objetivo inicial señalado al comienzo de este artículo, es decir, ver cómo fue la influencia que los parques nacionales de los Estados Unidos hicieron de Pedro Pidal y Bernaldo de Quirós, Marqués de Villaviciosa de Asturias, el impulsor de dicha figura en España y de la ley que, en 1916, se aprobaría para dar paso a la creación de los dos primeros y significativos parques nacionales, Covadonga y Ordesa.

\section{La figura de Pedro Pidal}

La vida de Pedro Pidal, como deportista y como defensor de la naturaleza, es de sobra conocida, por lo que interesa aquí centrarse en lo que significó su viaje por Estados Unidos y su posterior proyecto de ley para crear en España la figura de parque nacional. Toda la filosofía de Pidal en lo que a los parques nacionales se refiere, así como la influencia que tuvo en él su visita a los de Yellowstone y Yosemite se recoge en su discurso en el Senado, del que era miembro, el día 14 de junio de 1916, con el que acompañó a su proposición de ley.

El discurso defiende con fuerza la necesidad de aprobar la ley con argumentos que van desde los problemas que los montes españoles sufren cuando la administración pública no se ocupa de su conservación a una exposición de las características de los niveles de protección que están adoptando ya algunos países. Las primeras palabras de su discurso son una exaltación de la naturaleza en la que el paisaje tiene un indudable protagonismo: 
De que yo la aliente, porque el entusiasmo, el fuego sacro por los esplendores de la Naturaleza, por la belleza de los paisajes, por la grandiosidad de los panoramas, es aliento de vida, de potencialidad, de exhuberancia, de energías, cosa de que vosotros no estáis faltos. (Pidal, 1916: 120).

No confía Pidal, sin embargo, en los pueblos y en los particulares al tratar el tema y es duro en sus palabras:

Y de que yo os ilustre en cuanto a los medios más conducentes y seguros para conservar y acrecer las bellezas naturales, tampoco habéis menester de mis escasas luces, que bien sabido tenéis, por experiencia, que la acción del Estado, en este caso, es la única eficaz y duradera. ¿Qué hacen si no los particulares en la conservación de los montes, por ejemplo? ¿Qué hacen si no los pueblos?... ¡Los particulares!; ¿no estáis oyendo decir todos los días que españoles, aun de los más conspicuos, están talando sus montes, realizando el vuelo de los mismos sugestionados por el lucro, y esto aun los poderosos? ¡Qué harán los que no lo sean! Y todo sin hacerse cargo que las claras de los montes son manchas en los propietarios... Pues, ¿y los pueblos?... "Lo que es del común es de ningún”, dicen, y allí donde el Ingeniero de Montes se descuida, o el guarda forestal no cumple con su deber, se tala o se destruye un monte. Y por eso las leyes desamortizadoras impidieron que pasasen a manos de particulares los montes públicos compuestos de haya, pino o roble, por considerarlos incapaces de conservar el vuelo de los mismos. Y por eso las leyes forestales reconocen la capitidisminución de los pueblos, considerándolos menores de edad en la administración de los montes públicos. (Pidal, 1916: 120).

Pese a este comienzo, el discurso de Pidal transcurre casi siempre sobre los aspectos positivos de la protección y su imperiosa necesidad para España:

...Un castillo, una torre, una muralla, un templo, un edificio, se declara Monumento Nacional para salvarlo de la destrucción. ¿Y por qué un momento, excepcionalmente pintoresco, con sus tocas de nieve, sus bosques seculares, su fauna nacional y sus valles paradisíacos no ha de declararse Parque Nacional para salvarlo de la ruina?... ¿ No hay Santuarios para el Arte? ¿Por qué no ha de haber Santuarios para la Naturaleza, para la Madre Naturaleza? (Pidal, 1916: 120).

A continuación, Pedro Pidal hace un recorrido por la historia de los parques nacionales en varios países, comenzando por los de Estados Unidos, lo que le permite hacer un discurso de contenido más político, relacionando la guerra de secesión americana y la posterior unidad nacional con la fuerza de la naturaleza y su amor por ella, cuya consecuencia será la creación del primer parque nacional, o, como dice el autor, firmando el bill del Senado que crea el primero del mundo, el de Yellowstone, «país de los prodigios».

Así lo ve Pidal: 
La concepción genial del pueblo americano consistió en haber comprendido que nada cautiva tanto la voluntad como la hermosura, y que hermosear, embellecer la Patria, es hacerla amable, adorable, y, como tal, una, fuerte, exuberante, fecunda, progresiva. Y el Norte y el Sur, cansados de la guerra, vieron su atención cautivada por las bellezas y los prodigios de Occidente, abierto por el General Grant el primer camino de hierro del Pacífico. (Pidal, 1916: 121).

Hace Pidal una curiosa comparación entre el paraíso de «ultratumba» que Mahoma ofrece a los que mueren en la guerra santa con el paraíso en la tierra que los Estados Unidos ofrecen a los que realizan el «trabajo santo»:

.... cuantos se esfuerzan trabajando, discurriendo, inventando en las grandes urbes, por entre casas de veinte, treinta, cuarenta y hasta cincuenta pisos. Para esos vela el Estado por la conservación de la Naturaleza inmaculada; que hay que respirar el oxígeno de las montañas, nutrirse de los efluvios de la Naturaleza en la totalidad de su composición armónica, para reponer el fósforo que diariamente se pierde en la atención sostenida, en la observación paciente, madre de la invención genial, que a la Patria honra y a la Humanidad entera beneficia. Y así vemos que la mayoría de los visitantes de los Parques Nacionales de América, que se cuentan por cientos de miles, son gentes de Nueva York y de Chicago. (Pidal, 1916: 121).

El progreso, tal y como lo entendieron los norteamericanos, se asienta en dos antorchas: «La antorcha que aclare el medio, el camino de la existencia, y la antorcha que ilumine el fin, la meta de la vida». La primera, la libertad; la segunda, la contemplación de la divinidad o la belleza.

Dos fueron los parques norteamericanos que visitó Pidal acompañado por uno de sus hijos, Yellowstone y Yosemite, quizá por ser el primero uno y el más famoso el otro, o por su gran pasión por la montaña, como se refleja al hablar de él. Sobre Yellowstone escribió Pidal:

Y se llama "país de los prodigios", por las prodigiosas fuentes termales intermitentes, llamadas Geysers, que, en medio de las praderías y los bosques, elevan al cielo sus columnas de agua hirviendo, llegando a alcanzar alguna en algunas ocasiones la altura de 90 metros; por los cráteres de barro en ebullición; por las rocas obsidianas; por las cascadas y los lagos; por la riqueza de la fauna y de la flora. Allí se abrigan los últimos rebaños de búfalos de América, los bisontes; los ciervos monumentales, llamados Wapitis; el Alce, el Mosa, los carneros salvajes, el antílope de las Montañas Rocosas, el puma, los osos negros, los pardos y los grises. (Pidal, 1916: 121).

El oso estará presente en distintos momentos de su intervención, aunque a veces de forma contradictoria en cuanto a su relación con estos animales y las características de los parques nacionales. Por un lado, a su vuelta de Estados 
Unidos, casi lo primero que hizo, según cuenta, fue cazar un oso enorme en Picos de Europa. Por otro lado, se congratula del lema del único, hasta ese momento, parque nacional de Suiza, cuyo lema es, según dice Pidal, «Aquí no se corta un árbol, y aquí no se pega un tiro».

De más interés resulta la relación que establece entre la conservación de los bosques y la de los valles, que viven, según defienden alemanes y norteamericanos, gracias a ellos. Eso permite a Pidal entrar en el asunto de la política forestal y su relación con la política hidráulica, citando a Gasset, como su máximo exponente, y recordando algunas palabras dichas por dos presidentes norteamericanos, Theodore Roosevelt y Woodrow Wilson:

Los pantanos artificiales, sin los bosques, que son los pantanos naturales, como dice Roosevelt, se convierten en depósito de las tierras que antes retenían las raíces de los árboles en las vertientes. Los pantanos artificiales se ciegan, se rellenan, y acaban por convertirse en cascadas; razón por la cual decía Wilson, el actual Presidente de los Estados Unidos, que un sistema nacional de riegos sin selvicultura será siempre un error nacional. (Pidal, 1916: 121).

Si Yellowstone es el primero y mayor de los parques norteamericanos, Yosemite es el más bello de todos.

El Yellowstone fue el valle que se elevó, pues está a 2.400 metros de altura sobre el nivel del mar; el Yosemita (sic.), en cambio, fue el valle que se hundió, pues está rodeado de paredes verticales de 900 a 1.000 metros de altura. Sus cascadas son las más altas del mundo; sus árboles, los más grandes; la célebre "sequoia gigantesca", que arranca derecha en competencia con los montes para escalar el cielo, y sus lagos, los que con mayor perfección reflejan la composición entera del paisaje. (Pidal, 1916: 121-122).

No puede olvidar al oso, y unido al significado de Yosemite, recuerda su encuentro con uno a la vez que comparte sus sentimientos ante aquellos paisajes y, también, el significado de la contemplación de los mismos.

Yosemita, en el leguaje de los indios, de los pieles rojas, quiere decir "el gran oso gris", y grande fue el que nos encontramos mi hijo y yo cuando bajábamos del "punto de la inspiración", y habíamos atravesado el "punto del artista". "Punto de la inspiración", llaman los americanos, aquel en que el paisaje nos sorprende, nos suspende, nos inspira. "Punto del artista", aquel, ya rebuscado, desde el cual el paisaje resulta más hermoso. Al salir del punto del artista, nos encontramos con el oso magnífico, corpulento, plantado en medio del camino, que se perdió tranquilamente en la espesura. (Pidal, 1916: 122).

El discurso de Pedro Pidal no se limita a las evocaciones o a repasar con cierto detenimiento la historia de los parques nacionales norteamericanos, 
sino que también repasa las políticas seguidas por algunos de los países más desarrollados del momento y que tienen unas sólidas políticas de defensa de la naturaleza. Canadá, Suiza, Argentina, Australia, Italia, Francia y Nueva Zelanda son, a su juicio, los países más avanzados en lo que a parques nacionales se refiere. De Nueva Zelanda destaca el hecho de que, además de siete parques nacionales, que protegen «los glaciares, los desfiladeros, las rocas y las cascadas», el hecho de que ya tenga un Ministerio de Turismo.

Especial atención dedicó Pidal a la situación alemana, que ya en 1910 había constituido la Sociedad para la creación de los Parques Nacionales en Alemania y Austria, con sede en Stuttgart, con la intención de crear en dichos territorios tres grandes parques nacionales (de 50 a 150 kilómetros cuadrados) siguiendo los ejemplos de Suiza y de Estados Unidos; además de recordar que ya han creado un parque natural protegido de los Alpes de Estiria. El primero de los parques estaría en los Alpes, el segundo en Alemania central, y el tercero al norte, en las landas del Lünebourg. El problema con el que se encontraron fue que Alemania tenía ya una densa red de ferrocarriles, por lo que tuvieron que optar por parques más pequeños pero numerosos. Entre ellos, señala Pidal el parque nacional de la selva virgen de Hasbruch, con encinas milenarias; la selva de Kubani, en Bohemia, con pinos y hayas de más de sesenta metros; o la reserva de ciento sesenta y siete hectáreas en la provincia de Brandenburgo en la que están prohibidas la caza y la pesca, no se puede cortar ni un árbol y ni siquiera recoger leña.

Sobre la política de conservación alemana, añade Pidal:

El profesor Conwentz fue el principal promotor de la protección a la Naturaleza, y el Gobierno prusiano instituyó en Berlín un Gabinete Central con esta misión, cuya dirección fue confiada a dicho profesor. Así, en el Lago de la Selva Negra, jamás se podrá cortar un árbol, ni en la Puerta Westfálica de la Weser explotar una cantera. La protección a la Naturaleza es allí signo mayor de la cultura. (Pidal, 1916: 124).

Ya en sus palabras finales, destaca el hecho de que fue Alfonso XIII quien propuso la idea de crear un parque nacional en Gredos para proteger la «capra hispánica», en peligro de extinción. También comparte la idea, en lo que a protección se refiere, pero no la forma, de la propuesta de la sociedad «Ciudad Jardín» de Barcelona y su iniciativa de crear futuros parques nacionales de Cataluña:

Pero, entiendo que, antes que los Parques Nacionales de Cataluña, que al ser de una región ya no podrían llamarse "Nacionales", y esto es evidente, debemos todos crear los PARQUES NACIONALES DE ESPAÑA. (Pidal, 1916: 125). 
Tras la intervención de Pedro Pidal, tomó la palabra el Conde de Romanones, Presidente del Consejo de Ministros, para exhortar a la aprobación de la ley y tomar las medidas necesarias en el futuro para su cumplimiento.

La ley se aprobó, en los mismos términos que la había presentado Pedro Pidal, el 7 de diciembre de 1916.

\section{FIGURA 5}

PARQUE NACIONAL SIERRA DE GUADARRAMA, DECLARADO EN 2013

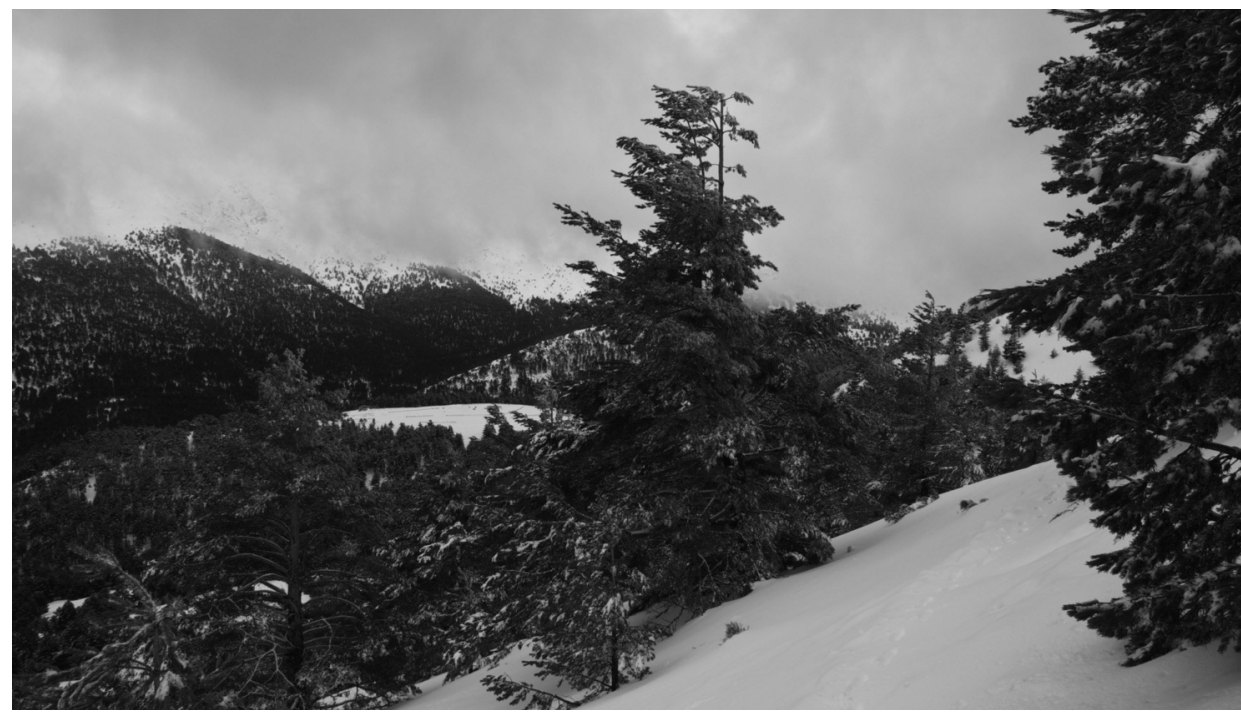

Fotografía: Manuel Mollá (2013).

\section{BiBLIOGRAFÍA}

Bowles, S. (1869): Across the Continent: A Stage Ride Over the Plains, to the Rocky Mountains, The Mormons, and the Pacific States, Springfield, Mass., S. Bowles and Company, 390 pp.

Cramton, L. C. (1932): Early History of Yellowstone National Park and its Relation to National Park Policies, Washington, D. C., United States Government Printing Office, $158 \mathrm{pp}$.

Cueto Mújica, F. A. (2006): "Los parques nacionales en México y Canadá: una visión general", Revista Mexicana de Estudios Canadienses (nueva época), 012, http://interpol.uasnet.mx/inv/revistas/. 
Emerson, R. W. (1904): Ensayo sobre la naturaleza. Seguido de varios discursos, Madrid, La España Moderna, 236 pp.

Emerson, R. W. (1914): Journals, en The Ralph Waldo Emerson Journals Digital Archives, X, http://www.perfectidius.com/Volume_10_1864-1876.pdf.

Fernández Sánchez, J. (1999): El hombre de los Picos de Europa: Pedro Pidal, marqués de Villaviciosa, fundador de los parques nacionales, Madrid, Organismo Autónomo Parques Nacionales, 349 pp.

Fernández Sánchez, J. y Prada Regel, R. (1996): Los parques nacionales españoles. Una aproximación, Madrid, Organismo Autónomo Parques Nacionales, 482 pp.

Gómez Mendoza, J. (1998): "The Persistence of Romantic Ideas and the Origins of Natural Park Policy in Spain", Finisterra, XXXIII/65, pp. 51-63.

Hernández-Pacheco, E. (1917): "Nota sobre el reciente decreto de creación de parques nacionales", Boletín de la Real Sociedad Española de Historia Natural, 17, pp. 149-150.

Huth, H. (1948): "Yosemite: The History of an Idea", http://www.yosemite.ca.us/ library/yosemite_story_of_an_idea.html\#foreword.

Martínez de Pisón, E. (1998): "Madrid y la Sierra de Guadarrama", en E. Martínez de Pisón, (coord.), Madrid y la Sierra de Guadarrama, Madrid, Museo Municipal, pp. 13-33.

Martínez de Pisón, E. (2009): Miradas sobre el paisaje, Madrid, Biblioteca Nueva, 288 pp.

Mollá Ruiz-Gómez, M. (2007a): "La Junta Central de Parques Nacionales y la Sierra de Guadarrama", Ería, 73-74, pp. 161-177.

Mollá Ruiz-Gómez, M. (2007b): "La Junta Central de Parques Nacionales y el paisaje en España (1916-1936)", en V. Paül i Carril y J. Tort i Donada (coord.), Territorios, paisajes y lugares, Cabrera de Mar, Galerada/AGE, pp. 113-122.

Mollá Ruiz-Gómez, M. (2015): "Las políticas de parques nacionales en España”, Ería, 97, pp. 157-171.

Ortega Cantero, N. (1998): "El descubrimiento cultural de la Sierra de Guadarrama", en E. Martínez de Pisón, (coord.), Madrid y la Sierra de Guadarrama, Madrid, Museo Municipal, pp. 81-114.

Ortega Cantero, N. (2014): "Paisaje, patrimonio e identidad en la conformación de la primera política turística española", Ería, 93, pp. 27-42.

Pidal y Bernaldo de Quirós, P. (1916): "Parques nacionales: proposición de ley y discursos pronunciados en el Senado por los Sres. Marqués de Villaviciosa de Asturias y Conde de Romanones el 14 de junio de 1916, Madrid", España Forestal, 14, pp. $120-125$.

Pidal y Bernaldo de Quirós, P. (1917): Lo que es un parque nacional y el parque nacional de Covadonga, Madrid, Ramona Velasco, 18 pp.

Pidal y Bernaldo de Quirós, P. (1919): El naranjo de Bulnes y Peña Santa, Madrid, Ramona Velasco, $30 \mathrm{pp}$.

Pidal y Bernaldo de Quirós, P. (1930): El lago de Enol, Madrid, Ramona Velasco, 9 pp. 
Pidal y Bernaldo de Quirós, P. (1934): El caso de los parques nacionales, Gijón, Tipografía La Industrial, $32 \mathrm{pp}$.

Pidal y Bernaldo de Quirós, P. y Zabala, J. F. (1918): Picos de Europa: contribución al estudio de las montañas españolas, Madrid, Club Alpino Español, (edición facsímil, 2010, Valladolid, Editorial Maxtor), 120 pp.

Runte, A. (1987): National Parks: The American Experience, Lincoln, University of Nebraska Press, 335 pp.

Russel, C. P. (1947): One Hundred Years in Yosemite, Berkeley \& Los Angeles, University of California Press, 226 pp.

Somoza Medina, J. (2009): "The national park concept in Spain: patriotism, education, romanticism and tourism", en W.,Frost, and C. M. Hall, (ed.), Tourism and National Parks. International perspectives on development, histories and change, London \& New York, Routledge, pp. 143-154.

Thoreau, H. D. (2004): The Maine Woods, Princeton, Princeton University Press, 347 pp.

Thoreau, H. D. (2010): Caminar, Madrid, Árdora, 64 pp.

Vargas Márquez, F. (1997): Parques Nacionales de México, 2 vols., México, D. F., SEMARNAP, 340 y 265 pp.

Whitney, J. D. (1870): The Yosemite Guide-Book: A Description of the Yosemite Valley and the Adjacent Region of the Sierra Nevada, and of the Big Trees of California, Sacramento, Authority of the Legislature, $200 \mathrm{pp}$.

Fecha de recepción: 22 de enero de 2015.

Fecha de aceptación: 27 de mayo de 2015. 